\title{
Grazing behaviour and forage selection pattern of heifers in the range
}

Akewusola, O. G., Babayemi, O. J. and Adebayo, A. A.

Department of Animal Science, University of Ibadan, Ibadan, Nigeria

Correspondingauthor: oakewusola@gmail.com

Abstract

The grazing behaviour of eight yearling white Fulani heifers was studied in two season of year in the south western zone of Nigeria. Time spent on different activities such as drinking, walking, grazing, resting and ruminating were determined using direct eye observation technique. The types of forage selected in both seasons were identified. Visual observations revealed that behaviour was influenced by seasons. The heifers spent 2, 8, 15, 14 and 62\% of their time drinking, ruminating, resting, walking and grazing respectively as overall percentage for the two seasons. The forage selection pattern revealed that forbs were mostly selected in the late dry season and grasses in the early rain season. The forages selected in the late dry season were Panicum maximum, Cynodon dactylon, Ipomea aquatical, Leucaena leucocephela, Centrosema mole and Althernanthera dentata. In the early rain season forages selected include Setaria bartata, Echinochloa stagirina, Pennisetum purpureum and Panicum maximum regrowth. It is therefore concluded that the study provides a quick insight into behavioural and forage selection pattern of heifers. Therefore the study can be used to assess grazing animal nutrition condition.

Keywords: Heifers, yearling, seasons, selection, forbs, grasses and legumes

\section{Introduction}

The success of the livestock industry anywhere in the world depends greatly on feed quantity and quality (Bamikole and Babayemi, 2004). Inadequate nutrition is one of the factors that generally affect livestock productivity. Nigeria has a wide diversity of climatic zones from the humid forest zone of the south to the very dry Sahel region of the north and mountainous cool belt of the plateau in the middle belt region. Vast areas of the forest region lie under the blood sucking insects challenge; hence the production of ruminant animal species is somehow limited. Despite the naturally endowed vegetations; there are still inadequate feeds and feedstuff for livestock in Nigeria. Grazing ruminants attempt to adapt to these zones and their adverse conditions by increasing the time for which they graze each day and also by dispersing more widely. The use of leaf of browse trees show potentials to augment depleted nutrients, being high in protein, vitamins and minerals but also contain anti nutrients (Babayemi, 2007). Leaf meal from browse plants is bulky and may have low shelf- life. The conventional seed protein sources such as groundnut and soya beans are scarce and expensive. As part of the new technology in animal husbandry, improved pastures produced more of dry matter of high nutritive value and lead to greater animal productivity but land available are used for arable crop production (Ademosun, 1976). Behavioural principle and practice of cattle provide a variety of solution to problems faced in managing and improving animal productivity. Grazed herbage is the cheapest feed source available for cattle and sheep and so maximizing its utilization can be obtained by studying the behavioural pattern of grazing animals. Livestock (especially) ruminant are the best assessors of the nutritive value of any feed than any other methods, as they always consume more of the forages that are high in protein than the high lignin containing forages 


\section{Grazing behaviour and forage selection pattern of heifers in the range}

(Babayemi and Bamikole, 2006). Forage selection by grazing animals reflects the best forage sample in terms of dry matter, nutrient composition and nutritive value. An insight into the plant species and their dominance in the late dry and early rain parts of the season may be vital for livestock farmers to strategize in formulating feeding regimes to meeting the animal's nutrient requirement for the remaining part of the off-season (Babayemi et al., 2007). The aim of this study therefore was to monitor the behavioural pattern of grazing heifers in the late dry and early raining seasons of the year and to determine the types of forages grazed by heifers in both seasons of the year.

\section{Materials and methods \\ Study area}

Study was carried out at range land within the Teaching and Research Farm, University of Ibadan. The location falls within $7^{\circ} 20^{\prime} \mathrm{N}, 3^{\circ} 50^{\prime} \mathrm{E}$ at an altitude of 200 $300 \mathrm{~m}$ above sea level. Site of experiment is of sub humid type having an annual rainfall of $38^{\circ} \mathrm{C}$. Total area of range land was 5 hectares and was composed of varying forages as reported elsewhere (Babayemi and Bamikole, 2006a). Range was divided into four grazing site using physical boundaries such as tarred road and buildings as means of demarcations. Animals were allowed to graze these sites in turns. The grazing session lasted for two months in late dry season (DecemberFebruary), and one month in early raining season (February- March).

\section{Cattle management}

On arrival, heifers were quarantined and acclimatized for two months, during which they were treated against endo and ecto parasites and placed on recommended antibiotics by the University veterinarian. Eight heifers with mean weight of $113.8 \mathrm{~kg}$
$( \pm 9.86)$ were of White Fulani breed. The heifers were obtained from cattle market, Bodija, Ibadan, Nigeria. Their initial weight was determined using girth belt. Heifers were tagged using wooden pendant and rope hung loosely on their neck. This was done for ease of identification. Heifers were managed under semi-intensive management and supplemented with ensiled cassava peel and Albizia saman pod mixtures.

\section{Grazing behaviour and forage selection}

Heifers were released into the range land at 9.00 and returned to kraal at 4.00. The direct eye observation technique (Adams et al, 1985) was used in monitoring grazing behaviour. Observation of the behaviour was done after 30 minutes of introduction of heifers into the range. Each animal was followed by an observer and each observer had a record sheet and stopwatch for recording and monitoring of the animals. A total of 5 recording were made daily on each animal, each recording lasted for 10 minutes and was done at hourly intervals for full range activities such as type of forage the animal bite, time spent grazing, ruminating, standing, walking, drinking and resting. Percentage time spent on each activity was calculated. Representative sample of the forage consumed/selected by the heifers was harvested daily and taken for identification at the botany department of University of Ibadan. Records of forages selected daily were kept. GPS (Global Positioning System) was used to determine distance covered by animals.

\section{Statistical analysis}

Data obtained on selected forages and grazing behaviour were subjected to analysis of variance (ANOVA) and significant difference occurred means were separated (Duncan (1955) using Statistical Analysis (SAS) package. 


\section{Akewusola, Babayemi and Adebayo}

\section{Results}

Presented in Table 1 are grazing activities of heifers on range. Percentage time spent on drinking ranged between $1.0 \%$ for late dry and $3.0 \%$ for early rain. In ruminating, it was ranged between $4.0 \%$ and $12.0 \%$, resting ranged between $8.0 \%$ and $21.0 \%$, walking ranged between $9.0 \%$ and $19.0 \%$ while grazing ranged between $57.0 \%$ and $66.0 \%$ for late dry and early rain seasons respectively. Significant differences existed among early rain and late dry activities indicating that lesser time was spent on all the grazing behaviour in late dry season. This might be attributed to high ambient temperature in this season. Thus foraging ability of cattle is low in late dry season. According to Krysl et al. (1993) grazing is affected by temperature, in very high temperature cattle will prefer to graze at night. As environmental temperature increases, grazing and grazing behavior reduces (Hessle et al., 2008). The overall percentage time spent in a grazing day in specific activities were summarized as indicated in Figure 1.The overall percentage for drinking, ruminating, resting, walking and grazing respectively are $1,8,14,15$ and $62 \%$.

Table 1: Percentage of grazing day spent on different activities by seasons

\begin{tabular}{llll}
\hline & \multicolumn{2}{c}{ Seasons } & \\
\cline { 2 - 3 } Parameters (\%) & Early rain & Late dry & 0.4 \\
\hline Drinking & $3^{\mathrm{a}}$ & $1^{\mathrm{b}}$ & 1.6 \\
Ruminating & $4^{\mathrm{c}}$ & $12^{\mathrm{b}}$ & 2.1 \\
Resting & $8^{\mathrm{b}}$ & $21^{\mathrm{c}}$ & 0.5 \\
Walking & $19^{\mathrm{a}}$ & $9^{\mathrm{c}}$ & 0.3 \\
Grazing & $66^{\mathrm{a}}$ & $57^{\mathrm{b}}$ &
\end{tabular}

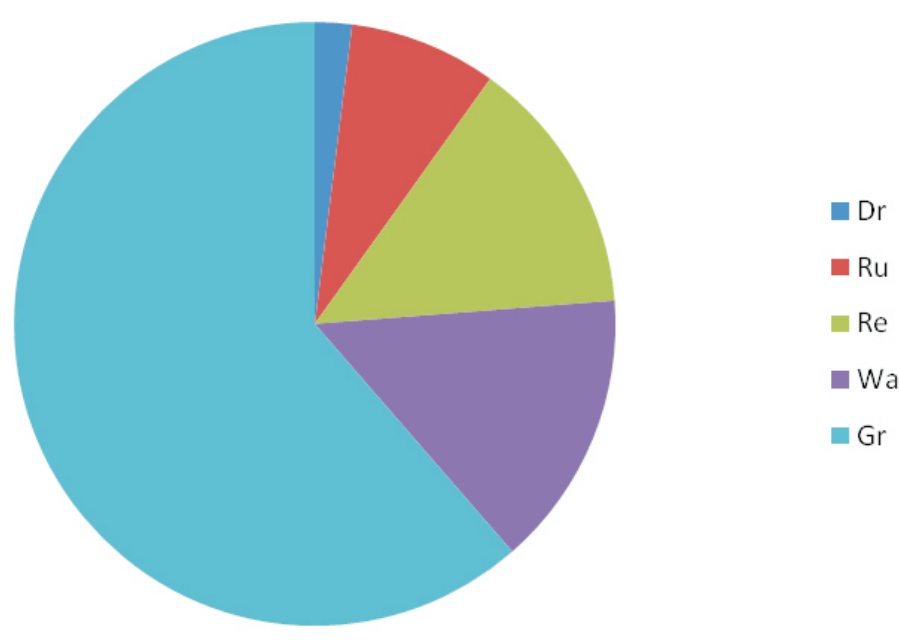

Figure 1: Overall mean of specific grazing activities of white Fulani heifers on range Dr: drinking

Ru: ruminating

Re: resting

Wa: walking

Gr: grazing 


\section{Grazing behaviour and forage selection pattern of heifers in the range}

Shown in Table 2 are the different forages grazed by heifers in the seasons. Eleven forage species were identified. They comprised of forbs, grasses, browse and legume. The percentage sward composition ranged between $9.1 \%$ for legume and browse and $54.5 \%$ for grasses. The few number of forage selected in the range might be due to physiological state (Rook et al., 2004) as grazing animals with lower maintenance requirements (i.e., dry cows) had reduced metabolic rates that may lead to less selective foraging behavior. Palatability is also a factor that affects selectivity. According to Vallentine (1990), palatability is a key component in selection of one forage plant over another. The forbs identified were Ipomea aquatica, Althernanthera dentata and Sarcolepis africana. The grasses included Cynodon dactylon, Echinochloa stagirina,Panicum maximum, Pennisetum purpureum and the regrowth of Panicum maximum. The Legume species was Centrosema mole while the browse species was Leucaena leucocephala. The percentage selectivity for grasses, legume, forbs and browse respectively are 54.5, 9.1, 27.3 and $9.1 \%$ indicating that grasses were more selected by the heifers thus more palatable than other forages

Table 2: Different forages grazed by White Fulani heifers in late dry and early rain seasons in sub-humid zone of Nigeria

\begin{tabular}{llll}
\hline \multirow{2}{*}{ Forbs } & \multicolumn{2}{c}{ Sward composition } & \\
\cline { 2 - 3 } Althananthera & Grasses & Legume & Browse \\
Dentata & Cynodon dactylon & Centrosema mole & Leucaena \\
& & Leucocephala \\
Echonochloa & \\
Ipomea Aquatica & Panirina & \\
& P.maximum maximum & \\
Sarcolepsis & regrowth & \\
Africana & Pennisetum & \\
& purpureum & \\
\hline
\end{tabular}

Table 3: Pattern of forage selection by white Fulani heifers in sub-humid zone of Nigeria

\begin{tabular}{lllll}
\hline \multirow{2}{*}{ Forages } & \multicolumn{2}{c}{ Month of Selection } & & \\
\cline { 2 - 3 } Grasses & Dec. & Jan. & Feb. & Mar. \\
Cynodon Dactylon & $\mathrm{Y}$ & $\mathrm{Y}$ & $\mathrm{Y}$ & $\mathrm{N}$ \\
Echinochloa Stagirina & $\mathrm{N}$ & $\mathrm{N}$ & $\mathrm{Y}$ & $\mathrm{Y}$ \\
Panicum maximum & $\mathrm{Y}$ & $\mathrm{Y}$ & $\mathrm{Y}$ & $\mathrm{N}$ \\
P. maximum re growth & $\mathrm{N}$ & $\mathrm{N}$ & $\mathrm{Y}$ & $\mathrm{Y}$ \\
Pennisetum purpureum & $\mathrm{N}$ & $\mathrm{N}$ & $\mathrm{Y}$ & $\mathrm{Y}$ \\
Setaria bartata & $\mathrm{N}$ & $\mathrm{N}$ & $\mathrm{Y}$ & $\mathrm{Y}$ \\
Forbs species & & & & \\
Althananthera dentate & $\mathrm{Y}$ & $\mathrm{Y}$ & $\mathrm{N}$ & $\mathrm{N}$ \\
Ipomea aquatic & $\mathrm{Y}$ & $\mathrm{Y}$ & $\mathrm{Y}$ & $\mathrm{N}$ \\
Sarcolepsis Africana & $\mathrm{Y}$ & $\mathrm{Y}$ & $\mathrm{Y}$ & $\mathrm{N}$ \\
Legume species & & & & \\
Centrosema mole & $\mathrm{Y}$ & $\mathrm{Y}$ & $\mathrm{N}$ & $\mathrm{N}$ \\
Leucaena leucocephala & $\mathrm{Y}$ & $\mathrm{Y}$ & $\mathrm{Y}$ & $\mathrm{Y}$ \\
'Y' denote grazed in that month & & & & \\
'N' denote not grazed in the month & & $\mathbf{1 9 7}$ & &
\end{tabular}




\section{Akewusola, Babayemi and Adebayo}

Presented in Table 3 are the forage species grazed by heifers in the two seasons under consideration (the late dry and early rain season). The result showed that forbs were mostly selected in the late dry while grasses dominated the early rain season. The browse was grazed throughout the seasons. Selectivity for forbs in the late dry season might be due to forage availability and quality. Dry seasons are off-season for most tropical forages. According to Peters (1992), drastic decline in forage quality was reported for grasses in dry season. Larbi et al. (1998), however, reported higher CP during the dry season in some species, such as Ficus exasperata, Senna siamea and Acacia angustissima, whereas opposite was observed for other browse species studied in southwestern Nigeria.

\section{Discussion}

Ratio between ruminating and grazing time were $1: 9,1: 17$, and $1: 5$ for the overall mean, rainy and dry seasons respectively. Although the value of the ruminating to grazing time ratio was only for the day light period when viewed together with Table1 a trend emerged linked to forage quality and intake. Grazing and ruminating times appeared to be related, low quality forage in the dry season resulted in longer ruminating and shorter grazing (intake) time, while the reverse was found in the better condition of rainy season.

Thereby corroborating the inference that intake is limited by forage quality. The 5 minutes observation period that can be used successfully to record grazing time (Adams et al., 1985) was confirmed in this present study. It has many obvious advantages over indirect technique which requires the use of device such as telescope (Funston et al 1990, Stobbs 1973) and vibracorder. These instruments are very expensive and require high labour input although they have their advantages. White Fulani heifers walked longer distances than Tarentaise cattle (D'Hour et al,1994) such that daily averages ranging from $0.9-26 \mathrm{~km}$. White Fulani walked more because of poor grazing resources due to the study environment which have structures and roads. These hindrances restricted movement of animals all leading to a more need for walking to search for feed. The percentage time spent grazing of $62 \%$, was within the range reported for herded cattle (Tribe, 1955) and non-herded cattle. Where heifers are herded, the influence of the herder dominated the individual expression of cattle. However, when it came to behaviour on which the herder had less influence on, e.g rumination, significant differences between grazing areas were observed due to differences in forage quality and water availability. Rumination time is known to vary with forage quality (Van Soest, 1994), which varied across areas and seasons. More time was spent drinking in the early rain season when there was plenty of surface water. Reason have been advanced for expecting longer ruminating period in the dry season when forage was at its lowest quality. Since they had access to forage of high quality and plenty of water in the rainy season, heifers should do more resting instead of less. However, it is possible that more resting occurred in the dry season because of high prevailing temperature and the desire of the heifers to avoid unnecessary effort. With increasing temperature, cattle rest for longer periods by seeking shades (Krysl et al., 1993). A similar walking time was observed; but it should be noted that in the dry season heifers devoted their entire walking time simply to walking where as in other season, grazing and walking occurred simultaneously. Heifers grazed for the shortest time in the dry season, when quality 


\section{Grazing behaviour and forage selection pattern of heifers in the range}

and quantity of forage were lowest but spent a relatively longer period in rumination.

There were more than one hundred plant species observed in the rangeland but eleven varieties composed of grasses, legumes and forbs were consistently grazed at one time or the other by the heifers. Most of the forages grazed by the heifers are available in south western of Nigeria (Aregheore and Yahaya, 2001). Gliricidia sepium and Leucaena leucocephala were available in both late dry and early rain season but the former was not observed to be browsed. Grazing and browsing of forages by ruminants is a selective event (Philip, 1993) and selection of forage is aimed at obtaining plant component with the highest nutritive value but the presence of anti nutritional factors or toxins also affect plant selection by ruminants especially cattle (Provenza,1995). The number of forages selected by the heifers as compared to large varieties of plant present on the range might be attributed to body size (Gordon and Illius, 1988) and level of production.

The forage selection study in the early rain season showed that Panicum maximum and Leucaena leucocephala were continuously grazed for the four month study period. Forbs were grazed all through the late dry season. Only two Legumes was observed to be consumed in the four month. Observation on the field showed that there is strong preference for Panicum maximum regrowth at the onset of early rain season and throughout the early rain season period (February - March). Pennisetum purpureum was available in both season under study but was not grazed until March. This might be due to maturation, high lignin content and drop in crude protein level (Areghore, 1996). All these observations corroborate the previous findings of (Omokaye, et al., 2001), that selected browse plant during the dry season in the sub-humid Nigeria will include Panicum maximum, Pennisetum purpureum, some weeds and forbs (Aregheore, 2001). Succulent and palatability might be factors responsible for high choice of forbs in the dry season as the process of lignifications of grasses could have been high (Smith, 1992) around this time. In the month when most of the forage species were observed not to have been grazed by heifers, forage biomass quantity play a large role. This observation corroborated the findings of (Aregheore, 1996) that marked seasonal changes affect the quality and quantity of forage and that quantity of forage declines rapidly in the dry season.

\section{Conclusion}

The study established that grazing behaviour provided an insight into how cattle behave at range, at different seasons. The study also established that animals are the best judge of what they eat. However, their natural judgment of feedstuff can be maximized and manipulated by farmers and researchers to optimise their output in terms of weight gain and production.

From this study, it can be recommended that the eleven species of forage selected by the white Fulani heifers can be harvested when they are available in abundant and processed as silage or meal. In this form the fibre content of the forages will be more digestible by grazing animals. Two, three or four species of the forage can be combined and ensiled depending on their availability.

\section{References}

Adams, D. C., Nelsen, T. C., Reynolds, W. L. and Knapp, B. W. 1985. Winter grazing activity and forage intake of range cows in the Northern Great 
Plains. J. Anim. Sci. 62: 1240.

Ademosun, A. A. 1974. Utilization of poor quality roughages in the derived savannah Zone. In: Loosli, J. K., Oyenuga, V. A. and Babatunde, G. M. Eds. Animal Production in the Tropics. Proceedings of the International Symposium on Animal production in the tropics, held at the University of Ibadan, Nigeria 26-29 March 1973. pp 152-166.

Aregheore, E. M. 1996. Natural grassland and ruminant interactions in the dry season in Delta State, Nigeria. World Review of Animal Production. 31(1-2): 74-79.

Aregheore, E. M. 2001. The effect of supplementation of crop residues based diets on the performance of steers grazed on natural pasture during the dry season. African Journal of 90Range and Forage Science, 18: 25-29.

Aregheore, E. M. and Yahaya, M. S. 2001. Nutritive value of some browses as supplement for goats. Malaysian Journal of Animal Science, 7(1): 29-36.

Babayemi, O. J. and Bamikole, M. A. 2006. Effect of Tephrosia candida DC leaf and its mixture with Guinea grass on in vitro fermentation changes as feed for ruminant in Nigeria. Pakistan journal of nutrition 5(1): 14-18.

Babayemi, O. J. 2007. in vitro fermentation characteristics and acceptability by West African dwarf goat of some dry season forages. Bioline International.

Babayemi, O. J., Odedire, J. A. and Daodu, O. 2007. Protein content and selection pattern of forbs, grasses, legumes and browse trees by Gudali cattle in Southwestern Nigeria. Tropical Journal of Animal Science Vol. 10, Nos. 1-2, Pp 481-485.

Bamikole, M. A. and Babayemi, O. J. 2004. Feeding goats with Guinea grass-verano style and nitrogen fertilizer grass with energy concentrate. Arch. Zootec., 53:1323.

D'hour, P., Houwuy, A., Coulon, J. B. and Garel, J. P. 1994. Walking and dairy cattle performance- Ann zootech 43.369-378.

Duncan, D. B. 1995. Multiple range and multiple F test. Biometrics, 1995, vol. 11,p.1

Funston, R. N. and Deutscher, G. H. 2004. Comparison of target breeding weight and breeding date for replacement beef heifers and effects on subsequent reproduction and calf performance. J. Anim. Sci. 82:3094-3099.

Gibb, M. and Orr. R. 1999. Grazing behavior of Ruminants. IGER Innovations.

Hessle, A., Rutter, M. and Wallkin, K. 2008. Effect of breed, season and pasture moisture gradient on foraging behavior in cattle on semi-natural grasslands. Journal of Applied Animal Behaviour Science. Vol. 111, Issues 1-2 Pp 108-119

Hodgson, J. 1982b. Ingestive behaviour. p. 113-138. In J.D. Leaver (ed.) Herbage intake handbook.

Gordon, I. J. and Illius, A. W. 1987. The allometry of food intake in grazing ruminants. J Anim ecol 50,989999.

Krysl, L. J. and Hess, B. W. 1993. Influence of Supplementation on Behaviour of Grazing Cattle. $J$. 


\section{Grazing behaviour and forage selection pattern of heifers in the range}

Anim. Sci.71:2546-55.

Larbi, A., Smith, J. W., Kurdi, I. O., Adekunle, I. O., Raji, A. M., Ladipo, D. O. 1998. Chemical composition, rumen degradation, and gas production characteristics of some multipurpose fodder trees and shrubs during the wet and dry seasons in the humid tropics. Animal Feed Science and Technology 72:81-96.

Omokaye, A. T., Balogun, R. O., Onifade, O. S., Afolayan, R. A. and Olayemi, M. E. 2001. Assessment of preference and intake of browse species by Yankassa sheep at Shika, Nigeria. Small Ruminant Research, 42: 203-210.

Peters, M. 1992. Evaluation of tropical pasture legumes for fodder banks in subhumid Nigeria. Ph.D. Thesis. Justus-Liebig-Universitãt, Giessen, Germany.

Provenza, F. D. 1995. Post ingestive feedback as an elementary determinant offood preference and intake in ruminants. J. Range manage 48, 2-17.

Rook, A. J., Dumont, B., Isselstein, J., Osoro, K., Wallis DeVries, M. F., Parente, G. and Mills, J. 2004. Matching type of livestock to desired biodiversity outcomes in pastures - a review. Biological Conservation. 119:137-150.
SAS 1999. SAS users guide statistics, SAS Inc. Cary, North Caroline, 1999. Edn.

Smith, O. B. 1992. Small ruminant feeding systems for small scale farmers in humid West Africa. In: Stares, J.E.S, Said, A.N. and Kategile, J.A. (Ed). The complementarity of feed resources for animal production in Africa. Proceedings of the joint Feed resources networks workshop held in Gaborone, Botswana, 4-8 March 1991. Africa Feeds research Network. ILCA (International livestock Centre for Africa). Addis Ababa, Ethiopia. pp 363-376.

Stobbs, T. H. 1973. The effect of plant structure on the intake of tropical pastures. I. Variation in the bite size of grazing cattle. Aust. J. Agric. Res. 24:809-819. University Press, Ithaca, USA, p. 119, 246-249.

Vallentine, J. F. 1990. Grazing management. Pages 178-184. Academic Press Inc. California.

Van Soest, P. J. 1994. Nutritional ecology of the ruminant. $2^{\text {nd }}$ edition. Cornell University Press, Ithaca, USA, P. 119, 246-49. Press. Ithaca, USA, P.119, 246.

Received: $18^{\text {th }}$ March, 2017

Accepted: $27^{\text {th }}$ July, 2017 